\title{
Et melopoetisk greb på Grundtvigsalmen
}

\author{
Lea Wierod
}

Grundtvigsalmerne er på samme tid digte, musik og teologiske udsagn, men de har primært været genstand for teologisk forskning - og i mindre grad litterær. Musikorienterede studier i Grundtvigsalmen har oftest forholdt sig underdanigt til teksternes indhold - og dermed nærmest reduceret sig til en teologisk-litterær subdisciplin. Af denne latente logocentriske præmis i salmestudiet følger idéen om teksten som den egentlige salme og melodien som dens subsidiære formidler. Det ligger implicit allerede i anvendelsen af genitiven "Grundtvigs salmer". Imidlertid kan denne anskuelse hverken forsvares ud fra Grundtvigs egen salmepoetik eller nutidige æstetiske teorier om, hvordan betydningsdannelsen foregår i medialt blandede udsagn. Jeg søger i denne artikel mod en udligning af det hierarkiske ord-musik-forhold i Grundtvigsalmestudiet. Det sker gennem en omlægning af forskningsspørgsmålet fra, i hvor høj grad melodien formår at forløse Grundtvigs salme, til, hvilken betydning der opstår i mødet mellem salmens ord og melodi under dens afsyngelse. ${ }^{1}$

\section{Indledning}

Som en del af det hymnologiske forskningsfelt er Grundtvigsalmeforskningen underlagt det generelle vilkår at være udspændt mellem flere discipliner. ${ }^{2}$ For salmeforskningen tegner teologien, litteraturvidenskaben

\footnotetext{
${ }^{1}$ Artiklen formidler mine studier i forbindelse med udfærdigelsen af ph.d.-afhandlingen: Formens funktion i salmesang. Melopoetisk metode i sanganalysen med serligt henblik på salmer med tekst af N.F.S. Grundtvig, Arts, Aarhus Universitet 2014.

${ }^{2}$ Om denne præmis som grundvilkår for ethvert overlap mellem kunst og kristendom, se Petersen, Auken \& Fleischer 1999.
} 
og musikvidenskaben sig mest markant. Generelt i hymnologien har de første to tendens til at sammensmelte; således anfører Christoph Albrecht $(1987,7)$ i sin Einführung in die Hymnologie, at eftersom hymnologien både adresserer salmernes tekstlige og musikalske aspekter, er den både et anliggende for teologien og for musikvidenskaben. Det litterært-poetologiske område nævnes ikke, og således er det underforstået, at de tekstlige aspekter - herunder litterære kvaliteter - må varetages alene af teologien. Forskningen i Grundtvigsalmerne har været præget af samme teologiske dominans. ${ }^{3}$ Præmissen er forståelig, når man betænker, at de teologiske og litterære forskningsområder har samme helt basalt-materielle empiri, nemlig skrevne tekster. Når der er tale om tekster, der på samme tid og ligefuldt er poetiske kunstværker og teologiske udsagn, ligger forskellen mellem områderne altså alene i erkendelsesinteressens karakter. For teologien ligger salmeteksternes værdi i, at de tjener et liturgisk-funktionelt formål - mens litteraturvidenskaben omvendt har tradition for at tilskrive en så markant brugsorienteret teksttype en lavere æstetisk værdi end et autonomt poetisk kunstværk (Nielsen 2009, 69). En sådan interessemæssig asymmetri har netop karakteriseret Grundtvigsalmeforskningen, som det blandt andet kommer til udtryk i Poul Borums kiastiske formulering af litteraturforskernes respektive grundtvigianernes modtagelse af Grundtvigsalmerne: "de første følte ham mindreværdig, de sidste mereværdig" (Borum 1983, 34).

Salmernes musikalske side risikerer ikke på samme måde at subsumeres i den teologiske dagsorden, da man vanskeligt kan se bort fra den helt konkrete stoflige forskel, der består mellem det tonemæssige og det tekstlige medium. Det ligger allerede i det åbenlyse forhold, at tekst og melodi (oftest) hidrører fra hver sin kreative kraft, henholdsvis poetens og komponistens. Imidlertid gør en anden risiko sig gældende for hymnologiens musikalske side; nemlig den, der ligger i, at kunstarternes indbyrdes forhold konstant er udsat for en kulturel evaluering. Vokalmusik, herunder salmer, er i sagens natur en kunstartsmæssig komposit af ord og musik, og relationen mellem disse to har op gennem historien undergået skiftende prioriteringer. Overordnet set udgøres polerne af en ordprioriterende (logocentrisk) og en musikprioriterende (melocentrisk) anskuelse. Hym-

${ }^{3}$ Ofte legitimeres dette gennem den antagelse, at kun en teologisk tilgang kan nå til bunds i forfatterskabet (Pedersen 2003, 151). 
nologiens musiksyn har, af forskellige historiske årsager, været præget af førstnævnte. Dette kommer især til udtryk i den - ofte uudtalte - præmis, at musikkens rolle i forhold til ordene er subordineret. Den antagelse, at en salmemelodis eksistensberettigelse består i at mediere og anskueliggøre digtets verbale udsagn, gennemsyrer musikalsk-hymnologisk litteratur og modsiges sjældent. ${ }^{4}$ Når jeg med denne artikel søger mod en forskningsmæssig opprioritering af Grundtvigsalmens melodiside, er det absolut ikke, fordi det skorter på behandling af denne. Snarere skal mit indlæg forstås som en udfordring til det underlæggende hymnologiske ideal om melodiens underordning i forhold til ordene. Jeg ønsker at spørge, hvilke erkendelser det kan afføde, når man betragter Grundtvigsalmernes betydning som resultatet af en vekselvirkning mellem ord og musik situeret i den konkrete forsamlings forening af ord og toner i salmens udsyngelse.

En sådan dagsorden flytter naturligvis fokus til det receptionsæstetiske. Ideen er, at man ikke betragter salmeteksten som et i sig selv færdigt og lukket hele, som så blot skal finde sig et melodisk talerør, men i stedet anskuer både tekst og melodi som en helhed, der ikke kan reduceres til nogen af enkeltdelene.

\section{Grundtvigsalmen og salmegenren}

Det antages, at Grundtvigs salmeproduktion tæller i omegnen af 1.600 tekster. Det er dog naturligvis langtfra alle af disse, der er - eller nogensinde har været - i anvendelse som salmer. For at en salmetekst kommer i anvendelse som salme, er to omstændigheder nødvendige: For det første skal den forsynes med en melodi, for det andet skal den implementeres i og af en syngende forsamling. Grundtvig har således strengt taget ikke skrevet 1.600 salmer, men 1.600 tekster, der aspirerer til at blive salmer. Hjemmel for en sådan hævdelse kan søges såvel i Grundtvigs egen salmepoetik som i nyere teoretisk forskning $\mathrm{i}$, hvordan en genre som salmen kommer i stand.

Da Grundtvig i 1843 påbegyndte arbejdet med salmebogstillægget Psalme-Blade til Kirke-Bod, korresponderede han blandt andre med sin ven

${ }^{4}$ Måske er dette standpunkt mest eksplicit udtrykt af Laub (1920, 169): "Al musikkens ret til at være ved gudstjenesten har den i sit forhold til menighedens ord". 


\section{LEA WiERøD}

præsten Peter Fenger. Af denne korrespondance fremgår det, at Grundtvig var særdeles opmærksom på melodispørgsmålets akutesse:

Det glæder mig, De tænker paa at komme herind, thi ogsaa jeg ønskede, naar mit Udkast omtrent er færdigt, at giennemgaa det med Dem og et Par andre Præstelige Venner, som veed hvad der kan synges med Lyst og nogenlunde Lethed, thi næst efter at Kirke-Psalmerne skal være indvortes passende, maae de for at være gode til deres Brug udvortes [være] lidt mere end blot syngelige, og derom har jeg ofte kun et svagt og altid kun et dunkelt Skiøn (Holm 2002, 48).

Teksternes sangbarhed prioriteres altså højt af Grundtvig, og det er klart, at formålet med denne sangbarhed er, at teksterne skal sættes i musik, så de kan komme i anvendelse. Grundtvigs egen salmepoetik anlægger en mere holistisk og mindre problematisk vinkel på tekst-musik-konglomeratet, end det ellers har været tilfældet, såvel i den generelle hymnologi som den specifikke Grundtvigsalme-reception. Det vil sige, at Grundtvig forstår succeskriteriet for blandingen af ordsiden og musiksiden som hvilende på det folkelige og simpelt sangbare. Hvad nu angår den anden omstændighed, jeg anførte som en nødvendighed for teksternes forvandling til salme - nemlig dens konkrete anvendelse - kan vi fremdrage Grundtvigs anmeldelse fra 1828 af en af Peter Fenger udgivet samling af Kingo-salmer. Her hedder det, at “(...) det, der i Kirke-Sangen opbygger og rører os, langt mindre er Psalmen i sig selv betragtet, end Menighedens inderlige deltagelse i den (...)" (Grundtvig 1828, 31). Ligeledes angiver Grundtvig i korrespondancen med Fenger, at salmernes kvalitet viser sig, når de bliver "prøvede hos Folket" (Holm 2002, 32).

Fra Grundtvigs egen hånd er der således godt belæg for at betragte salmegenren som konstitueret af en blanding af tekst og melodi og tilvejebragt gennem sin situerede udførelse. Fra et mindre biografistisk og mere modtagerorienteret perspektiv peger nyere tiltag inden for den genreteoretiske forskning på, at genrer ikke er stabile kategorier, men i langt højere grad skabes og forhandles i og af kulturelle fællesskabers pragmatiske omgang med dem. ${ }^{5}$ Først og fremmest er en given genre defineret ved den

5 Genreteori er gået fra at være et anliggende for litteraturvidenskaben til at være en tværgående paraplydisciplin som følge af den indsigt, at genrer absolut ikke be- 
sociokulturelle problemstilling, den henvender sig til; genrer er opstået og har fået deres form på baggrund af en helt konkret og tilbagevendende retorisk situation (Miller 1984). Man bemærker den grad af overensstemmelse en sådan definition på salmegenren har med Grundtvigs ovenfor skitserede salmepoetik. Inden for rammerne af en sådan synsvinkel giver det ikke mening at betragte Grundtvigsalmen som en tekst, der foreligger færdig og afrundet fra Grundtvigs hånd, og som blot skal have tilført et melodisk appendiks. Det giver for en streng betragtning ikke engang mening at omtale salmerne som "Grundtvigs" og dermed indikere et forfattermæssigt ejerskab, der virker forpligtende på tekstens melodisætter(e). Processen, hvorved et artefakt indskrives i salmegenren, involverer først en sammensmeltning af tekst og melodi og herefter en optagelse i en forsamling (naturligvis oftest en menighed under en gudstjeneste), der anvender og forstår artefaktet som en salme. Hvis disse parametre ikke finder sted, forbliver det pågældende artefakt udelukket fra den retorisk situerede "inderlige deltagelse", der berettiger til status af "salme". ${ }^{6}$

\section{Melopoetisk metode i Grundtvigsalmestudiet}

Salmens flermediale og situationsbundne karakter kan virke indlysende, men har en tendens til at gå upåagtet hen i fortolkningen og forståelsen af Grundtvigsalmen. Der skal her ikke argumenteres for, at salmeforskningens musikalske side må styrkes, men snarere at selve formålet for salmeanalysen må omdefineres. Hvis en salmemelodis formål er at formidle og fremhæve tekstens budskab, bliver vurderingskriteriet for salmens tekstog melodisamspil, hvorvidt melodien løser denne af teksten dikterede opgave. Sådan en tilgang var forståelig og forsvarlig på tidspunktet for Laubs

høver være hverken litterære eller kunstneriske kategorier - alle former for kulturelle ytringer danner genrer, og denne genredannelse regulerer på et fundamentalt plan vores forstålse og kommunikation (Auken 2014, 12 og 18).

${ }^{6}$ En tekst og/eller melodi, der forgæves har aspireret til indlemmelse i salmegenren, kan med hymnologen Henrik Glahns ord høre under salmerepertoirets "spildprocent" (2000, 74). C.J. Brandt, der overtog Grundtvigs redaktion af salmebogsrækken Fest-Psalmer, udtrykte salmegenrens flermediale karakter ved at beskrive salmer uden melodi som "vingeløse fugle" (citeret efter Nørfelt 1983, 16). 
(1920) eller endda Arnholtz' (1952) kritik af Grundtvigsalmernes melodier. For disse var det 19. århundredes proklamering af musikkens autonome transcendensetablerende magt mere præsent og musikken dermed en potentielt farligere magt i kirkeligt regi. For en nutidig æstetik fremtræder et sådant kunstartsideologisk synspunkt dog forældet. ${ }^{7} \mathrm{Nu}$ består faren snarere i den ubemærkethed, hvormed ét af medierne i et flermedialt udsagn tildeles underrang, sådan som det ofte kan ske i analyser af samspillet mellem ord og melodi i en sang. Det udtrykkes i musikforskeren Nicholas Cooks udredning af musikkens rolle i multimediale former som f.eks. sang:

When we talk about songs, we say that the composer highlights a poet's choice or underlines their meaning. But there is a danger in this terminology, widespread as it may be. When we use such terms to describe song, we imply that the music is supplementary to the meaning that is already in the words $(1998,21)$.

Her udtrykkes en holdning til blandede mediale kunstartsformer, som betragter betydningsdannelsen som et resultat af hvert medium (i salmens tilfælde ord og musik) samt selve blandingen i sig selv. Mødet mellem ord og melodi afstedkommer et nyt udsagn, som ikke kan reduceres til nogen af delene hver for sig. Hermed lægges op til en bevægelse væk fra det logocentriske sangsyns hegemoni og hen imod en anskuelse af melodien som ligeværdig medspiller i udsigelsen.

Dermed ikke sagt, at forkæmperne for en logocentrisk tilgang til Grundtvigsalmen generelt har underkendt melodiens evne til at rumme et udsagn. I Laubs opfattelse har salmemelodien absolut en meningsbærende funktion - det er netop dette faktum, der muliggør, at musikkens budskab kan karambolere med ordets: Hvis ikke salmens musikside kunne rumme betydning, ville der ikke være den store fare forbundet med at

\footnotetext{
7 Der verserede dog på Laubs tid en sideløbende uenighed om, hvorvidt salmers tekst- og melodisamspil bør behandles normativt - som en diktering af hvad der bør synges i kirken - eller mere pragmatisk-deskriptivt - som en redegørelse for hvad der bliver sunget i kirken: Birkedal-Barfod, udgiveren af den store Menighedens Melodier (1914), fremsatte den tese, at man ikke burde foreskrive menigheden, hvad den skulle synge - blot seks år før Laub udgav sit reformværk (1920), der netop må siges at være sådan en foreskrivelse.
} 
indhente f.eks. romanceagtige melodier i salmetekst-repertoiret. Men nu ligger det sådan for Laub og hans meningsfæller, at melodien netop ikke er et meningstomt medium for teksten, men derimod selv er ladet med betydningsindhold - f.eks. referencen til de populære syngespils verdslige og løsslupne handlingsunivers. Da nu musik ifølge denne opfattelse har et betydningsindhold i sig selv, står muligheden åben for, at tekstens indhold kan modsiges af melodiens.

Den holdning, at musik i sig selv kan være bærer af et betydningsindhold, ligger også til grund for nyere tids fundering af musiksemiotik som en selvstændig teoretisk disciplin, og i den forstand kan vi - omend anakronistisk - kalde Laub en musiksemiotiker. Af den historiske diskurs på det musiksemiotiske område kan man udlede to typer musikalsk betydningsdannelse: på den ene side det rent musikinterne betydningsindhold, som genereres af aspekter som rytme, intonation og emotionelt ladet klang, og på den anden side den kontekstuelle, kulturelt etablerede "etos", som kan tilskrives f.eks. bestemte melodiske intervaller eller musikalske stilarter (se Monelle 1992, 1-31, for et overblik over udviklingen af musiksemiotiske positioner). Den første type af betydningsdannelse skal forstås som en naturligt iboende udtrykskraft i de musikalske virkemidler - såsom temposkift eller tonespring, der formidler et bestemt følelsesindhold, eller musikalske figurer, der f.eks. med trinvise toneskift mimer et fænomen som en rislende bæk eller lignende. Den sidste type musikalsk betydning er konventionel i den forstand, at den får sin funktion i forhold til et specifikt fællesskab - og dens gyldighed består kun inden for rammerne af denne; f.eks. en hornkvint-figur, som anvendes for at fremmane et hyrde- eller jagtscenarie. Ganske vist kan sådanne konventionelt betydningsladede musikalske vendinger tages op og genanvendes af en anden kultur eller epoke, men pointen er, at da er betydningsindholdet ikke længere det samme - som f.eks. når Beethoven trækker på en hornkvint-figur, som i 1700-tallet refererede til landlig idyl, men 100 år senere og i et nyt æstetisk miljø får en pasticheagtig og arkaisk tone (Tarasti 2002, 7). De to typer af betydningsdannelse overlapper dog ofte, og det er ikke altid muligt at udpege, om et bestemt musikalsk betydningsindhold er naturligt eller kulturelt bestemt. Den affektive kvalitet i musikalske skalaer såsom de diatoniske, dur-mol og kirketonearternes kan siges at svæve mellem på den ene side at være kulturelt betinget og på den anden side at være karakteriseret af intersubjektiv og en høj grad af transkulturel enighed. 
Det er f.eks. svært at pege på de iboende træk, som gør det lave andet trin i den frygiske skala mørk og sørgelig - alligevel skal der ikke nogen stor overvindelse til, for at en nutidig modtager intuitivt fornemmer, hvorfor middelalderen ofte anvendte frygisk til "agnus Dei"-temaet. Opdelingen i den iboende og den kulturelle musikalske betydningsdannelse er altså konceptuel i højere grad end virkeligheds-afspejlende.

Laub skelner da heller ikke mellem disse to typer semiotisk funktion i musikken. Hans teoretiske forklaring på musikkens betydning holder sig til den iboende semiosis:

Når 'tonen' brugt i almindelig menneskelig tale virkelig 'siger noget', næmlig [sic] om den talende er glad, bedrøvet, eller hvad han nu kan være, hvorfor skulle den så pludselig holde op med at kunne gøre det, når den anvendes i kunst? (Laub 1920, 90)

Principielt ligger musikkens betydningsdannelse ifølge denne udlægning i basale, prækulturelle mekanismer som sprogets emotionelt ladede toneglidninger. Derimod befinder hele Laubs konkrete eksempelapparat - som udgør hans angreb på den kirkelige romance - sig inden for den anden type, den kulturelt og konventionelt bestemte betydningstilskrivelse. Romancetonen er upassende som kirkemelodi, fordi dens semiotiske udsagn er lig med dens kontekstuelle ophav som koncertsals- og teatermusik (f.eks. 1920, 153 og 174). Det er påfaldende, at Laub trods sin historiske bevidsthed og betoning af det kontekstuelle element alligevel opfatter det som sandsynligt, at fremtidens salmesangere fortsat vil have den samme referenceramme (f.eks. 1800-tallets syngespil og vaudeville). Dette har vist sig ikke at være tilfældet. De selvsamme kompositoriske effekter (høje melodispring, spændt harmoni etc.), som via det 19. og tidlige 20. århundredes kulturelle kode forbandt de romantiske melodier med ukirkelige kontekster, er siden gradvist blevet en fast del af salmerepertoiret.

Den pragmatisme, som præger tilblivelsen af en genre som salmen, gælder både tekst- og melodisiden. Grundtvigs digt "Kirkeklokke mellem ædle malme" 1845 har været vurderet "ubrugelig som salme” på grund af sit tematiske indhold, der er af selvbiografisk karakter, idet det hentyder kraftigt til Grundtvigs egen opvækst (Jensen \& Bugge 1972, 15). På trods af det er denne salme blev optaget i hele fire autoriserede (samt 
nogle uautoriserede) salmebøger og må således siges at have fundet vej ind i salmegenren. ${ }^{8}$

Ovenstående udredning kan opsummeres i følgende to pointer. For det første må salmemelodiens betydningsindhold betragtes som fluktuerende afhængigt af skiftende retoriske situationer. De faktorer, der tillader en melodi (såvel som en tekst) medlemskab i salmegenren, skal ikke primært findes i tekst- eller musikinterne parametre, men i dens pragmatiske og diskursive konstituering som salme. Det har den konsekvens for salmens fortolkning, at fokus må flyttes fra et produktionsorienteret til et receptionsæstetisk tyngdepunkt. Hovedspørgsmålet for den musikalske Grundtvigsalmeforskning omformuleres under denne optik fra "hvorledes formår denne melodi at omsætte og forløse Grundtvigs tekst?” til det mere værdineutrale og mindre logocentriske "hvilket nyt udsagn skabes i samspillet mellem tekst og melodi i netop denne konkrete kombination, og hvordan påvirkes det relevante afsyngnings-kollektiv heraf?"

For det andet: Idealet om melodien som tekstens uskyldige formidler er en praktisk umulig illusion. Melodien vil, i momentet for salmens afsyngelse, altid påvirke tekstens budskab, hvad enten det er på det rent "salmeinterne" plan i forholdet mellem tekst og melodi eller på det kontekstuelle plan gennem forskellige associative betydninger knyttet til melodien.? Dette vil jeg nu forsøge at anskueliggøre med et eksempel.

\section{Alt hvad som Fuglevinger fik}

Anvendelsen af "punktkarakteristik" - den detailprægede tonemaleriske udhævning af enkeltord og stemninger i en salmetekst - er et af de fremtrædende kritikpunkter fremsat mod salmemelodier med angiveligt ukir-

8 Digtet optoges delvist i Tillag til Psalmebog for Kirke- og Huus-Andagt (1873) og Psalmebog for Kirke og Hjem (1899) samt i sin helhed i de to seneste autoriserede udgaver af Den Danske Salmebog (1953 respektive 2003), jf. Kjærgaard 2003, 723.

9 Både tekst og melodi kan gennem inkulturation komme til at blive "mættet" af hinanden i en bestemt kombination. For melodiens vedkommende har Lawrence Kramer døbt denne mekanisme "speaking melody" - det at melodien, selv nonverbalt nynnet eller forespillet, fremmaner teksten $(2005,127)$. For tekstens vedkommende, og inden for det hymnologiske felt, har Ole Brinth talt om, hvordan ordene kan have svært ved at "holde sig melodien fra livet" (2007, 294). 
kelig stil (se f.eks. Arnholtz 1952, 32). Årsagen er, at der herved skabes en alt for tæt kontakt mellem ord og musik, hvorved musikken indrømmes en udpræget delagtiggørelse i salmens udsagn. Den historiske strid mellem ord og musik har også en melocentrisk modpol, og i hymnologien har dette f.eks. vist sig gennem jubilus-melismerne (en lang, ordløs melisme på sidste stavelse af ordet "alleluia") i den gregorianske sang eller i 1800-tallets idé om "absolut musik", dvs. at musikken har en uafhængig udsigelsesmagt (Petersen 1996, 137). Når et sådant musikalsk ideal kombineres med tekst i sang, tilføjer musikken en selvstændig fortolkningsdimension til det samlede flermediale udsagn, og det er altså denne omstændighed, som falder det logocentriske salmeideals tilhængere for brystet, når de føler, at den tilføjede dimension ikke svarer til deres billede af tekstens betydning.

Problemet er, at selv om punktkarakteristik (som på ordet "brat" i Christian Barnekows "Kom Gud Helligaand, kom brat"-melodi) og melismatisk tonemaleri (som på ordet "tonestige" i A.P. Berggreens "Velkommen igen, Guds Engle smaa”-melodi) undgås, kan melodiens affekt på salmens ord ikke holdes nede. Det bliver særlig tydeligt i tilfælde af strofisk variation af tekstens metrum, hvor melodien så at sige tvinges til at tage stilling til én af strofernes fortolkning af metret. Et sådant tilfælde har vi i Grundtvigs tekst "Alt hvad som Fuglevinger fik" (1851, 581). Dette digt med sekslinjede jambiske strofer udfordrer stærkt sin form ved at lade størstedelen af den første strofe (verslinje et, to, fire og seks) være gennemsyret af korjambisk variation, dvs. inversion af den første jambe i hver verslinje, så denne bliver til en trokæ: $\smile--\smile-\smile-$ (således første linje: "Alt hvad som Fuglevinger fik"). Denne omvending af metret er ikke til stede i samme grad i de yderligere strofer i teksten, og slet ikke i strofe to, der forløber glat jambisk: $-\smile-\smile-\smile-$ (første linje: "Min Sjæl, du har af alt paa Jord"). Tekstens første strofe opviser altså en stærk interferens mellem metrets ramme og sprogets prosodiske udfyldning heraf - hvorimod anden strofe omvendt lader det strofisk-metriske og det sprogligt-rytmiske niveau smelte uproblematisk sammen. Der følger meget forskellige poetiske effekter af disse to strategier. Sammenstillingen af formmæssig interferens i første strofe over for konformans i næste kan, om man vil, tolkes som en ikonisk gengivelse af tekstens semantiske indhold: Første strofe afbilder en dialektisk interferens mellem den jordiske ve og vånde og den himmelske Gud, som råder bod herpå. Anden strofe forbliver derimod på 
det jordiske niveau og beskriver den frihed og problemløshed, hvormed det jordiske subjekt drager sin ånde i sang.

En tekst som denne vil ved sin fusion med en melodi og sin implementering i sang oftest trække den rent tekstlige tvetydighed i én af de mulige retninger (i dette tilfælde den korjambisk interferensfyldte eller den jambisk ligefremme). Laubs melodi gør det sidste (nodeeksempel transkriberet efter 1918, 6):

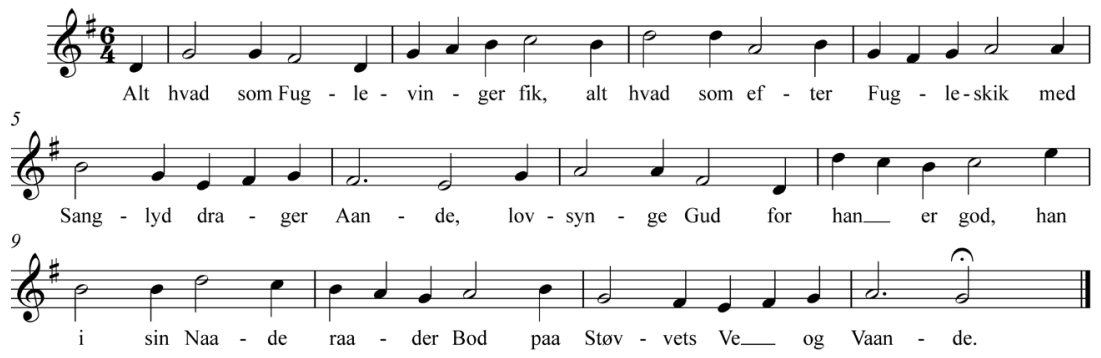

Med alle tænkelige midler er der i denne melodi indikeret jambisk struktur: optakt, et indledende opadgående kvartspring og en tredelt taktart. Resultatet bliver, at denne tekst-melodi-kombination konsoliderer Grundtvigs udnyttelse af rytme/metrum-interferensen i første strofe og lader anden strofe fremstå som det mest uproblematiske "melopoetiske match". Man kunne have forestillet sig den omvendte situation, som ville fremkomme ved tekstens parring med en stærk korjambisk melodi som f.eks. Christian Bulls “At sige Verden ret farvel”-melodi (Rung 1868, 20): Med sin uoptaktiske, firdelte form fasttømrer denne melodi den korjambiske struktur og afstedkommer dermed, at det pludselig er de jambiske strofer, der fremstår som anomalier under afsyngningen.

Der er dog også en tredje mulighed, nemlig en melodi, der lader tekstens metriske flertydighed forblive åben. Grundtvig har selv i et håndskrift angivet melodien "Lær mig, o Skov, at visne glad", hvilket ifølge Henrik Fibiger Nørfelt sandsynligvis skal henvise til den tyske folkevisemelodi fra ca. 1530, som i dag figurerer under titlen "O, kommer hid dog til Guds Søn” (Nørfelt 1983, 39; jf. også Kjærgaard 2003, 20). Denne melodi er metrisk ambivalent, ikke mindst på grund af de tre korte toner $\mathrm{i}$ begyndelsen af hver takt efterfuldt af to lange. Resultatet af denne tekstmelodiforbindelse bliver en større fleksibilitet i retning af såvel metrum 


\section{LEA WiERøD}

som rytme, eller med andre ord: en dobbelt melodisk åbenhed mod både den jambiske og den korjambiske side af teksten.

Den betydningsbærende metriske flertydighed i Grundtvigs tekst kan altså omsættes melodisk på flere divergerende måder - men ingen af tekstmelodiforbindelserne kan undlade at påvirke teksten og dirigere den i en bestemt retning. Til denne betragtning lægger sig spørgsmålet om salmens rent praktisk-situationelle afsyngelse. Grundtvigs egen melodiangivelse er her et illustrativt eksempel, da melodien er en luthersk koral, som har haft mange melodiske varianter. ${ }^{10}$ En sammenstilling af melodiens første to fraser, taget fra otte forskellige melodibøger fra den første officielle danske lutherske salmebog, Hans Thomissøns fra 1569, til nu, viser, at melodien har haft en bred vifte af forskellige historiske udformninger (se Wierød 2014, 109):
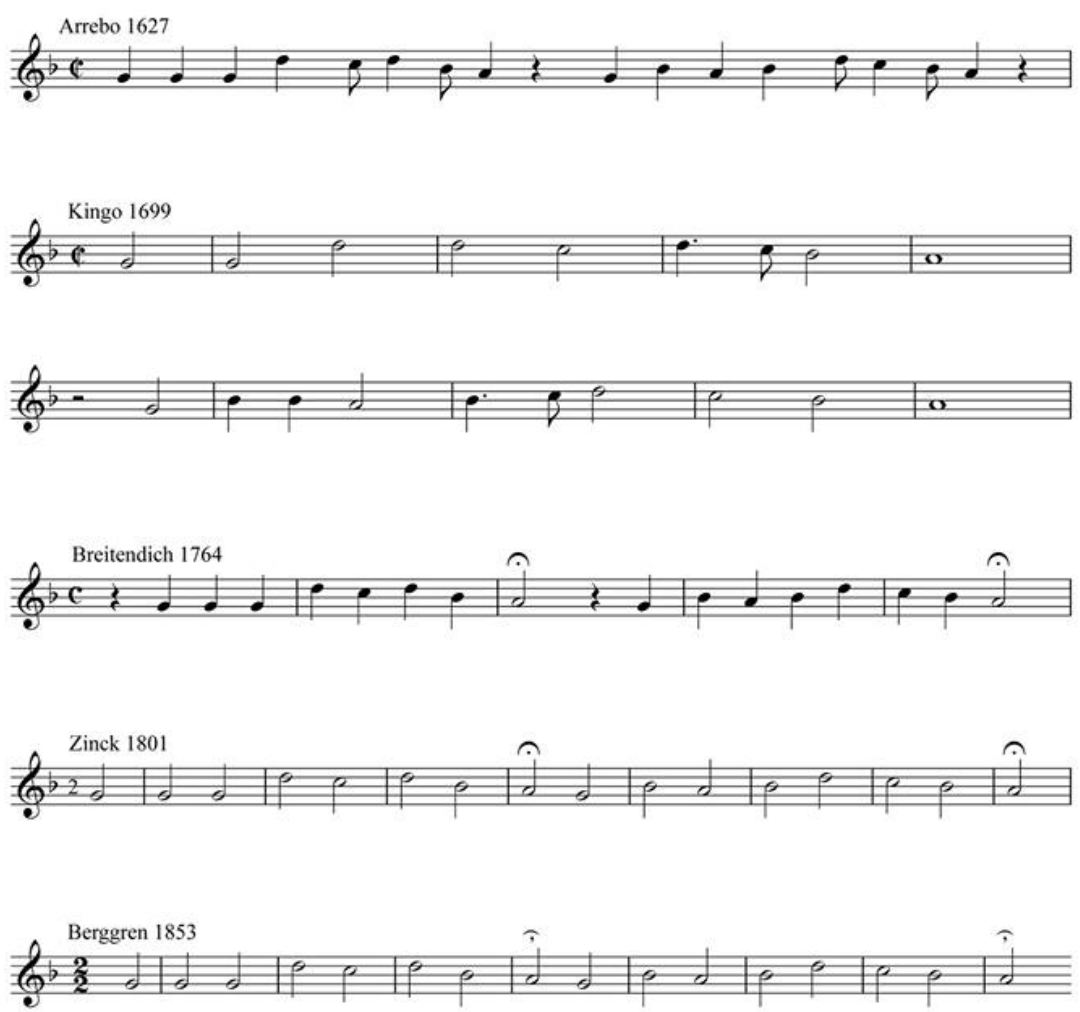

$\overline{10}$ Malling daterer melodiens tyske forlæg til ca. $1530(1964,179)$. 


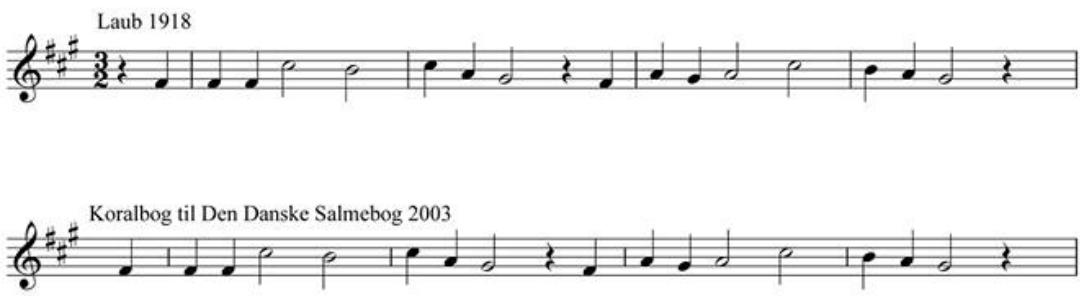

Hver af disse forholder sig lige så forskelligt til Grundtvigtekstens formmæssige virkemidler som de ovenfor gennemgåede alternativer. Hertil kommer de mange uskrevne udførelsesmæssige varianter, som kan forekomme fra menighed til menighed - samt påvirkningen fra melodiernes associative tilhørsforhold. Ved sin optagelse i Fest-Psalmer knyttedes teksten f.eks. til Emil Hartmanns melodi til "Som Forårssolen morgenrød”, hvilket kan tænkes at fremmane en påske-tolkning for et nutidigt kirkeligt fællesskab. ${ }^{11}$

Med denne sidste betragtning lægges også op til vigtigheden af at forstå afsyngningsfællesskabet og afsyngningssituationen. Ingen af de her fremdragne analytiske observationer af påvirkningen mellem musik og tekst har naturligvis nogen effekt, hvis ikke de føles af de syngende under den ritualiserede udførelse af salmen. Jeg har fremført, at musikken aldrig kan undgå at påvirke ordene i salmen, men dette gælder selvsagt kun under den samlede udførelse af tekst og melodi - og f.eks. ikke i situationer, hvor salmens tekst tilegnes individuelt som læsepoesi.

Der kan også argumenteres for, at en tekst først kan tilskrives salmegenren, når den sættes sammen med en melodi (jf. Wierød 2014, 74). Ud fra dette synspunkt vil en salmes udsagn altid være et resultat af en bestemt tekst-melodi-blanding, som opstår, når et konkret fællesskab afsynger den. Tekst-melodi-samspillet påvirker i denne konkrete situation da ganske vist sangerne - men lige så vigtigt er det, at påvirkningen er gensidig. Salmegenren har det bemærkelsesværdige karakteristikum (som den deler med fællessang generelt), at i afsyngningssituationen er dens afsendere sammenfaldende med dens modtagere. Da salmesang ikke er designet til kon-

${ }^{11}$ Kjærgaard anfører, at denne kombination ofte har været anvendt $(2003,20)$. Hartmanns melodi forekommer i Kalhauge 1876, 44, og da teksten jo optoges i Grundtvigs salmebog i 1870 (altså tæt på udgivelsestidspunktet for denne melodibog), forekommer det sandsynligt, at netop denne tekst-melodi-alliance kan have været anvendt. 
certfremførelse, er der ikke forskel på salmens sangere og dens tilhørere. De mange deiktiske markører i salmetekster er derfor af uhyre vigtighed for salmen: Salmens "jeg” og "vi” skal kunne inkludere mange forskellige individer på én gang, og ydermere skal de kunne transcendere de mange perioder, en salme som Grundtvigsalmen traderes gennem. Min pointe er, at succeskriterierne for en sådan tilegnelse af afsyngningskollektivet for salmens vedkommende ikke afhænger af tekstens budskab alene, men i lige så høj grad af musikken.

Der ligger en stærk anerkendelse af vigtigheden af selve salmeformens betydning i Christian Thodbergs arbejde med Grundtvigs salmer. Thodbergs udsagn om, at salmerne ingenlunde blot er "snakkesalige fordoblinger af forkyndelsen på prædikestolen” (Thodberg 1989, 14), kan tages til indtægt for samme syn på salmegenrens funktion, som jeg skitserede ovenfor: Salmeformen eller -genren tager over dér, hvor de prosaisk-semantiske former kommer til kort. Den vægtlægning på det sanseligt-æstetiske i salmen som poetisk-musikalsk udtryk, der kommer til udtryk i ovenfor anførte Grundtvigcitater, bekræftes ligeledes af f.eks. Helge Toldbergs iagttagelse af, hvordan Grundtvigs poesi har "fonetisk, sjældnere semantisk sammenhæng” (Toldberg 1945, 59). Mit ønske er at videreføre sådanne observationer med denne tilføjelse: Med til salmeformen hører melodien, og den er lige så lidt et appendiks til salmen, som tekstens form er det til tekstens indhold.

\section{Bibliografi}

\section{Verker af Grundtvig}

- (1828), "Thomas Kingos Salmer og aandelige Sange" i Theologisk Maanedsskrift, København, A. G. Rudelbaach, 1-36.

- (1851), "Alt hvad som Fuglevinger fik" i C.J, Brandt og R.Th. Fenger (red.) (1851), Dansk Kirketidende VI, nr. 36, København, J. C. Scharling. 


\section{ET MELOPOETISK GREB PÅ GRUNDTVIGSALMEN}

\section{Verker af andre forfattere}

Albrecht, Christoph (1987/1973), Einführung in die Hymnologie, Göttingen, Vandenhoeck \& Ruprecht.

Arnholtz, Arthur (1952), "Grundtvigs salmer og deres melodier" i GrundtvigStudier 1952, 7-38.

Auken, Sune (2014): "Meget, meget lille genreteori" i Sune Auken \& Christel Sunesen (red.) (2014), Ved Lejlighed. Grundtvig og genrerne, København, Spring, $12-24$.

Birkedal-Barfod, Ludvig (1914), Menighedens Melodier I-II, København, Wilhelm Hansen.

Borum, Poul (1983), Digteren Grundtvig, København, Gyldendal.

Jensen, Th. Borup og K. E. Bugge (1972), Salmen som lovsang og litteratur I-II, København, Gyldendal.

Cook, Nicholas (1998), Analysing Musical Multimedia, Oxford, Oxford University Press.

Glahn, Henrik (2000), Salmemelodien i dansk tradition 1569-1973, København, Anis.

Hanslick, Eduard (1984/1854), "Vom Musikalisch-Schönen. Ein Beitrag zur Revision der Ästhetik der Tonkunst”, i Carl Dahlhaus og Carl Zimmermann (red.), Musik zur Sprache gebracht. Musikästhetische Texte aus drei Jahrhunderten, Kassel, Bärenreiter, 300-305 (uddrag).

Holm, Jette (2002), "Psalmeblade til Kirke-Bod. En brevveksling mellem Grundtvig og hans præstevenner i foråret 1843" i Grundtvig-Studier 2002, 24-73.

Kalhauge, Viggo (1876), Fuldstandig Samling af Melodier til N. F. S. Grundtvigs Kirke-Salmebog. Fest-Salmer, København, E.L. Thaarup.

Kjærgaard, Jørgen (2013), Salmehåndbog I-II, København, Kgl. Vajsenhus' Forlag.

Koralbog til den Danske Salmebog (2003), Vejle, Kroghs Forlag.

Laub, Thomas (1918), Dansk Kirkesang. Gamle og nye Melodier, København, Wilhelm Hansen.

- (1920), Musik og kirke, København, Gyldendal.

Monelle, Raymond (1992), Linguistics and Semiotics in Music, London, Routledge.

Nielsen, Erik A. (2009), Kristendommens retorik. Den kristne digtnings billedformer, København, Gyldendal. 


\section{LEA WIERøD}

Nørfelt, Henrik Fibiger (1983), En Ny Sang i Danas Mund. En registrering og vurdering af melodivalget for og nu til N.F.S. Grundtvigs a-salmer $i$ Den danske Salmebog, København, P. Haase \& Søn.

Pedersen, Kim Arne (2003), "Den teologiske Grundtvigforskning siden anden verdenskrig”, i Hanne Sanders og Ole Vind (red.) (2003), Grundtvig. Nyckeln till det danska?, Göteborg, Makadam, 150-179.

Petersen, Nils Holger (1996), "Liturgy and Musical Composition" i Studia Theologica, 50:2, 125-143.

Petersen, Nils Holger, Sune Auken \& Jens Erik C. Fleischer (1999), "Indledning” i Transfiguration, 1, 7-19.

Rung, Henrik (1868), Tillag til Weyses Choralbog. 2. betydelig forøgede Opl., København, E. L. Thaarup.

Tarasti, Eero (2002), Signs of Music. A Guide to Musical Semiotics, Berlin, Mouton de Gruyter.

Toldberg, Helge (1945), "Oplevelsens betydning i Grundtvigs poesi” i Orbis Litterarum, 3:1, 59-107.

Wierød, Lea (2014), "Formens funktion i salmesang. Melopoetisk metode i sanganalysen med særligt henblik på salmer med tekst af N.F.S. Grundtvig”, Aarhus (ph.d.-afhandling). 